\title{
Phylogeny and biogeography of hogfishes and allies (Bodianus, Labridae)
}

Francesco Santini $^{\text {a, }},{ }^{,}$Laurie Sorenson ${ }^{\mathrm{a}}$, Michael E. Alfaro ${ }^{\mathrm{a}}$

${ }^{a}$ University of California Los Angeles, Department of Ecology and Evolutionary Biology, 610 Young Drive South, CA 90095 Los Angeles, USA

* Corresponding author:

Department of Ecology and Evolutionary Biology, University of California Los Angeles, 610 Young Drive South, CA 90095 Los Angeles, USA. Phone: +1 310794 5019;

E-mail: francesco.santini@alumni.utoronto.ca

\begin{abstract}
Bodianus wrasses comprise one of the most diverse genera of labrids. Also known as hogfishes due to the presence of a large pig-like snout, Bodianus species are found in warm waters across the Pacific, Atlantic and Indian Oceans. To this date no densely sampled molecular phylogeny is available for this group, and a single morphological study did not include two genera (Clepticus and Semicossyphus) that have been shown to belong within hogfishes. Our study produced the first multi-locus molecular phylogeny of Bodianus species, and corroborated the non monophyly of this group without the inclu-
\end{abstract}


sion of the Creole wrasse (Clepticus) and the sheepheads (Semicossyphus). We further showed that hogfishes and allies started to radiate during the Early Miocene, $\sim 20 \mathrm{Ma}$, and that while this group originated in the Indo-western and South-western Pacific, it experienced multiple episodes during which it successfully invaded different geographic regions and/or ocean basins.

Keywords. Bodianus, Clepticus, Semicossyphus, phylogeny, biogeography.

\section{Introdution}

The wrasse genus Bodianus includes 43 currently recognized species distributed across all warm oceans. Most species occur in shallow, tropical waters less than 70 meters of depth or in coral reef habitats, but a number of species are known to occur at depths in excess of 150 meters or in temperate waters (Gomon, 2006; Froese and Pauly, 2014). Commonly known as "hogfishes" due to an elongate snout, Bodianus wrasses are characterized by a laterally compressed body, a prominent frontal shelf on their neurocranium (absent in B. cylindriatus and B. thoracotaeniatus; Gomon 2006), and a sharp angle at the anteroventral edge of the dentary. Like most wrasses, a number of hogfishes are sequential hermaphrodites, changing sex during their life cycle, generally from female to male.

The greatest diversity of hogfishes is found in the Indo-western Pacific, but a number of species are also known from the South-western and North-western Pacific, the Eastern Pacific, the Western Indian Ocean, as well as both the Eastern and Western Atlantic, prompting questions regarding the age of this group, when and where the radiation of Bodianus began, and how did the various hogfish lineages disperse to 
achieve their present day distribution. Unfortunately currently there is no molecular phylogeny available that includes more than five species of Bodianus (Westneat and Alfaro, 2005; Alfaro et al. 2009; Cowman et al 2009; Kazancloglu et al. 2009). This makes it impossible to determine whether there were one or multiple transitions between oceanic basins (e.g., Pacific to Atlantic, or viceversa), or if there were multiple events of colonization, for example from the Western Atlantic into the Eastern Pacific before the final closure of the Isthmus of Panama. In light of the recent suggestions that the closure of the isthmus may have occurred much earlier than commonly thought (Bacon et al. 2015), it would also be important to determine when the split between the closely related species that occurr on the two sides of the Isthmus may have split from one another.

Furthermore, all large scale molecular studies of labrid relationships published to date (Westneat and Alfaro, 2005; Alfaro et al. 2009; Cowman et al 2009; Kazancloglu et al. 2009), point to the paraphyly of Bodianus without the inclusion of the genera Clepticus and Semicossyphus. Both genera are very small, with only three currently described species in each. While the creole wrasses of the genus Clepticus are found in the Western and Eastern Atlantic, the sheephead wrasses of the genus Semicossyphus are only present in the Pacific, with one species found in the North-eastern Pacific (the California sheephead), one in the Galapagos, and a third in the North-western Pacific. The only detailed phylogeny currently available for Bodianus is that published by Gomon (2006). Based on the parsimony analysis of a dataset of 43 morphological characters, which included 23 of the extant 43 Bodianus species, ten subgeneric lineages were 
recognized. Unfortunately, neither Clepticus nor Semicossyphus were included in the sampling.

For this study we assembled a dataset that includes 22 species of Bodianus, as well as five other closely related labrid species, to test the monophyly of the genus, and produce the first time-calibrated phylogeny for hogfishes and allies. We used four new markers that have not been used in any of the major studies of labrid inter-relationships (Westneat and Alfaro, 2005; Alfaro et al. 2009; Cowman et al. 2009; Kazancloglu et al. 2009), thus providing an independent test of the monophyly of hogfishes. We also used the program BioGeoBears to compare different biogeographic models in order to investigate the region of origin of hogfishes, and whether this group experienced multiple episodes of transitions between oceanic basins.

\section{Materials and methods}

\subsection{DNA extraction and amplification}

We secured tissue samples for 14 species of Bodianus, one species of Clepticus, two species of Semicossyphus, and two outgroups through loans from university or museum collections, or purchases through the pet trade (Table S1). We obtained sequence data from GenBank for eight additional Bodianus species, bringing our final sampling to 22 species of Bodianus, and 27 total species. We included Pseudodax moluccanus and Choerodon zamboangae as outgroups on the basis of recent studies of labrid higher level relationships (Westneat and Alfaro, 2005; Alfaro et al., 2009;

Cowman et al., 2009; Kazancloglu et al., 2009), 
We extracted DNA from muscle tissue samples or fin clips stored in $70 \%$ ethanol using the Qiagen DNasy Blood and Tissue Kit (Qiagen, Valencia, CA, USA) following the protocol suggested by the manufacturer. Two mitochondrial genes, cytochrome oxidase subunit I (coxl) and cytochrome b (Cytb), and two nuclear genes, early growth response gene $3(E G R 3)$ and rhodopsin $(R h)$, were amplified using the polymerase chain reaction (PCR). Primers and PCR conditions were obtained from the literature: Ward et al. (2005) for coxl; Sevilla et al. (2007) for Cytb; Chen et al. (2013) for EGR3; and Chen et al. (2003) for $R h$. We used ExoSap (Amersham Biosciences) to remove the excess dNTPs and unincorporated primers from the PCR products. Purified products were cyclesequenced using the BigDye Terminator v.3.1 cycle sequencing kit (1/8th reaction) (Applied Biosystems) with each gene's original or additional internal primers used for amplification. The cycle sequencing protocol consisted of 25 cycles with a 10 -s $94^{\circ} \mathrm{C}$ denaturation, 5-s of $50^{\circ} \mathrm{C}$ annealing, and a 4-min $60^{\circ} \mathrm{C}$ extension stage. Sequencing was conducted at the Yale University DNA Analysis Facility using an ABI 3730xl DNA Genetic Analyzer (Applied Biosystems). We used the barcode of life database (http://www.barcodinglife.com/index.php/IDS_OpenIdEngine) to verify the identification of our tissue samples, and retained only the samples that produced cox I sequences having 99\% or higher similarity to corresponding sequences in the database.

\subsection{Phylogenetic analyses}

We used Geneious 5.4 (Drummond et al., 2011) to inspect the sequence chromatograms and assemble them into contigs, and used MUSCLE (Edgar, 2004) to align the consensus sequences for each individual gene. We then inspected the 
alignments by eye for accuracy, and trimmed the sequences at the $3^{\prime}$ and $5^{\prime}$ ends to minimize missing characters. The final data matrix consisted of $651 \mathrm{bp}$ for coxl, $1058 \mathrm{bp}$ for $C y t b, 767 \mathrm{bp}$ for $E G R 3$, and $829 \mathrm{bp}$ for $R h$, for a total of 3305 nucleotides used in the concatenated analyses. We deposited all the sequences that we generated for this study in GenBank (Table S1). We used jModelTest (Posada, 2008) to select the best fitting model of sequence evolution from the candidate pool of models that can be utilized in MrBayes 3.2 (Ronquist et al., 2012) using corrected Akaike information criterion (AICc; Akaike, 1973), but did not include the proportion of invariant sites parameter in the candidate pool, as this parameter is already taken into consideration by the gamma parameter (Yang, 2006). jModelTest selected $\mathrm{HKY}+\mathrm{G}$ as the best model for all loci.

We concatenated the four individual gene datasets in Mesquite 2.75 (Maddison and Maddison, 2011), and ran maximum likelihood analyses using RAxML (Stamatakis, 2006), with each individual gene partition assigned a GTR $+\mathrm{G}$ model, the RAxML model closest to the jModelTest results. We ran 500 fast bootstrap replicates. We also used MrBayes 3.2 (Ronquist et al., 2012) to perform Bayesian analyses. We partitioned the concatenated dataset by locus and assigned the HKY $+\mathrm{G}$ model. We ran multiple replicates with two analyses of 10 million generations each, with four chains (one cold, three heated) sampling every 1000 generations. We used Tracer 1.6 (Drummond and Rambaut, 2007) to check the trace files and ensure that the chains had reached convergence, and discarded the first $25 \%$ of trees as burnin. We combined the postburnin trees to obtain a 50\% majority rule consensus tree and compared the topologies of the different replicates to each other to assess support for the results of the analyses. 
To generate the timetree, we analyzed the concatenated alignment as four unlinked gene partitions, after having assigned $\mathrm{HKY}+\mathrm{G}$ to each locus. We used uncorrelated lognormal priors in BEAST 1.8 (Drummond and Rambaut, 2007) and assigned a birth-death prior to the rates of cladogenesis. We ran two analyses of 10 million generations each, with sampling every 1000 generations. We used Tracer 1.6 (Drummond and Rambaut, 2007) to inspect the trace files, ensuring that the chains had reached convergence and the ESS values for all parameters were greater than 200 . We removed the first $10 \%$ of the trees from each analysis as burnin, used LogCombiner to merge the files with the remaining trees, and TreeAnnotator (Drummond and Rambaut, 2007) to obtain a timetree. As no fossils can presently be assigned to either Bodianus or other closely related wrasse lineages (Carnevale, 2015), we employed two different strategies to date the tree. First we ran analyses using the Miocene fossil of Trigondon jugleri (Schultz and Bellwood, 2004) to date the split between Pseudodax moluccanus and the rest of this clade. This fossil has been used in several time-calibration studies of wrasse relationships (Alfaro et al., 2009; Cowman et al., 2009), and is the only fossil that can be placed with confidence within the crown Hypsigenyine. However, this fossil is from sediments that have been dated at about 14 my ago (Schultz and Bellwood, 2004), while that node appears to be much older in the molecular chronograms (i.e., $32 \mathrm{my}$ in Alfaro et al., 2009; 33.7 my in Cowman et al., 2009). We also selected three key nodes in the Alfaro et al. (2009) timetree and used these as secondary molecular calibration points for additional analyses (with a single secondary calibration for each analysis): the split between Pseudodax moluccanus and the rest of this clade and the split between Choerodon zamboangae and the remaining taxa. For these secondary calibration points 
we used the younger age of the $95 \%$ highest posterior density (HPD) as the offset, and the older age of the $95 \%$ HPD for the soft upper bound.

All phylogenetic analyses (using RAxML, MrBayes and BEAST) were run on the Cipres portal v. 3.3 (Miller et al., 2010) and all tree files have been archived in Dryad (accession number pending).

\subsection{Historical biogeography}

To investigate the biogeographic history of the Bodianus clade we performed biogeographic reconstruction with our time tree using the $R$ package BioGeoBEARS (Matzke 2013). We used the dispersal-extinction-cladogenesis model (DEC; Ree, 2005) and the BayArea model (Landis et al., 2013) both with and without the founder-event speciation (indicated as $+\mathbf{J}$ ). The fit of each of the different models was assessed using the Akaike information criterion (AIC) (Matzke, 2013). We did not constrain the directionality or timing of dispersal in our analyses and we set the maximum number of ancestral areas to three. Data on distribution of the species included in out study were obtained from Fishbase (Froese and Pauly, 2014). We identified seven different geographic areas inhabited by our species: the Western Atlantic (from here on referred to as WA), the Eastern Pacific (EP), the Indowestern Pacific (IWP), the Western Indian Ocean (WIO), the South-western Pacific (SWP), the North-western Pacific (NWP) and the Eastern Atlantic (EA), all of which correspond to well-established, or complexes of closely related, marine biogeographic provinces (Briggs and Bowen, 2012). Due to the widespread distribution 


\section{of several species across some of these regions, such as the IWP, and the already high numbers of areas, we chose not to further subdivide these areas.}

\section{Results}

3.1 phylogeny of Bodianus

Both maximum likelihood and Bayesian analyses produced virtually identical topologies, with only one discordant node (Fig 1). Our results show that Bodianus is a paraphyletic genus, with two other genera (Clepticus and Semicossyphus), nested within it. Clepticus appears to be the sister taxon to Bodianus anthoides, while the two species of Semicossyphus, each other's sister taxa in our analyses, are the sister lineage to Bodianus scrofa. Our topologies show high support, both in Bayesian posterior probabilities (PP) over 0.95 and maximum likelihood bootstrap proportions (BSP) over $90 \%$ for a number of different groups of Bodianus species (all branches marked by a star in Fig. 1): Bodianus flavifrons + B. frenchii; B. oxycephalus + B unimaculatus; $B$. bimaculatus + B. opercularis; B. tanyokidus + B. trilineatus; B. axillaris + B. mesothorax sister to B. diana + B. dictynna; B. diplotaenia sister to B. pulchelus $+B$. rufus, with this clade being the sister taxon to a clade that includes the following species, all sequential sister taxa to the others: B. speciosus, B. eclancheri, B. perdition, $B$. bilunulatus, and B. macrorus.

All BEAST analyses produced the same topology (Fig. 2), which recovers all the same subclades and the highly supported nodes found in the RAxML and MrBayes topologies, even though the relationships among some of the subclades are different. The clade of Bodianus flavifrons + B. frenchii sister to B. oxycephalus + B unimaculatus, and 
the $B$. bimaculatus $+B$. opercularis are still the sequential sister lineages to all the remaining Bodianus + Clepticus + Semicossyphus, as in the MrBayes and RAxML topologies. After these lineages, the clade formed by B. speciosus, B. eclancheri, B. perdition, B. bilunulatus, and B. macrorus, which in the RAxML and MrBayes topologies appears to be deeply nested within the Bodianus + Clepticus + Semicossyphus group, is the next lineage to branch off, followed by B. diplotaenia + (B. pulchelus $+B$. rufus). The relationships among the remaining species show Clepticus + B. anthoides sister to B. tanyokidus + B. trilineatus, while the Semicossyphus + B. scrofa group is the sister taxon to (B. axillaris + B. mesothorax $)+($ B. diana + B. dictynna $)$.

\subsection{Divergence times of Bodianus and historical biogeography}

Regardless of the choice of secondary calibration, the BEAST analyses recover very similar results for all the nodes, with broadly overlapping 95\% HPD (see table S2). We will discuss here the ages of the tree in which the calibration point had been applied to the split between Pseudodax and the remaining species. The split between Pseudodax and the remaining species in our sampling is dated at $28 \mathrm{Ma}(\mathrm{HPD})$, while that of Choerodon and Bodianus + Clepticus + Semicossyphus is dated at 27 Ma (21-36 Ma 95\% HPD). The crown Bodianus + Clepticus + Semicossyphus starts diversifying $\sim 20$ Ma (15-28 Ma 95\% HPD), with all major Bodianus lineages originating during the Miocene between 17 and 9 Ma. The Clepticus + B. anthoides is $\sim 10 \mathrm{Ma}(6-16 \mathrm{Ma} 95 \%$ HPD), while the two species of Semicossyphus diverged from one another $4 \mathrm{Ma}$ (2-7 Ma 95\% HPD), after having split from B. scrofa 11 Ma (7-17 Ma 95\% HPD). 
The $\mathrm{DEC}+\mathrm{J}$ and BayAreaLike $+\mathrm{J}$ models obtain scores that are substantially better than these of the simple models (i.e., without the jump dispersal parameter) (Table S3), even though the difference between the score of the $\mathrm{DEC}+\mathrm{J}$ model and the BayAreaLike $+\mathrm{J}$ model is not large (Table S3). In the text that follows we report and discuss the results of the $\mathrm{DEC}+\mathrm{J}$ model, which obtained the better score of all models, but we report the results of the BayAreaLike $+\mathrm{J}$ model in the supplementary material (Fig. S2). The DEC $+\mathrm{J}$ model recovers an ancestral area formed by the IWP and the SWP with an immediate split into two lineages, one with predominantly SWP distribution, formed by the clade that includes Bodianus flavifrons, frenchii, oxycephalus and unimaculatus, and a second lineage that includes all remaining taxa in our study. Within the first lineage our analysis inferred two Pliocene transitions from a SWP ancestor to different areas: the first involves the $B$. frenchii lineage moving into the IWP, while the second involves the B. oxycephalus lineage moving into the NWP.

The biogeographic history within the second lineage, ancestrally distributed in the IWP shows multiple transitions in different geographic regions and oceanic basins. The Bodianus opercularis lineage appears to cross the Indian ocean to invade the WIO towards the very end of the Miocene, $\sim 6 \mathrm{Ma}$. The next lineage to branch off from the main Bodianus clade is hypothesized to have invaded the EA between $\sim 16$ and $\sim 11$ Ma. The only species sampled in our study still in the EA is Bodianus speciosus; other taxa from this groups established themselves in the EP, giving origin to the extant $B$. eclancheri, and reinvaded the IWP and WIO. The third lineage to split from the main Bodianus group includes the EP B. diplotaenia, as well as two WA species, $B$. rufus and B. pulchelus. The split between the Bodianus diplotaenia and its sister lineage appears to 
have occurred $\sim 7 \mathrm{Ma}$, while the two WA taxa separated at the very beginning of the Pliocene, 5 Ma. An Atlantic/Pacific split is also seen int he next lineage to originate, with the WA creole wrasse Clepticus parrae having split from the IWP Bodianus anthoides $\sim 10 \mathrm{Ma}$. Within the remaining members of the Bodianus clade we observe several additional transitions: at least two recent (Late Pliocene) transitions from IWP ancestors to WIO extant species are observed in B. diana and B. trilineatus; we further observe a second EA/EP clade that includes Bodianus scrofa (EA), as well as the two species of sheephead wrasses, the EP California sheephead (S. pulcher) as well as the Asian sheephead (S. reticulatus). While the split between the sheephead lineage and its sister taxon dates to the Late Miocene, $\sim 11 \mathrm{Ma}$, the California and Asian sheepheads split at the beginning of the Pliocene, $~ 5$ Ma.

\section{Discussion and conclusion}

Our analyses revealed a robustly supported molecular phylogenetic hypothesis for hogfishes that corroborates the paraphyly of Bodianus without the inclusion of the Clepticus creole wrasses and the Semicossyphus sheephead wrasses. We also recover a number of well supported groups that are also congruent with several of the subgeneric lineages identified by Gomon (2006), even though our sampling and Gomon's (2006) sampling only partially overlap. Our analyses recover a clade that includes $B$. bimaculatus and opercularis, corresponding to the subgenus Trochocopus of Gomon (2006), a group that is characterized by small size ( $\sim 18 \mathrm{~cm}$ or less, Gomon, 2006), with

some species, such as B. Bimaculatus reaching sexual maturity at length of just $\sim 8 \mathrm{~cm}$. A second clade includes $B$. frenchii and unimaculatus corresponding to Verreo, a group that 
Gomon (2006) defines on the basis of the reduction of procurrent caudal fin rays to seven. Bodianus axillaris and mesothorax corresponding to the subgenus Lepidaplois, which morphologically is characterized by the presence of a juvenile color pattern with contrasting pale spots in identical positions on a dark background (Gomon 2006). The clade including B. perditio and B. speciosus corresponds to the subgenus Diastodon, defined by the presence of a distinct row of small peripheral teeth, while the clade that includes B. diplotaenia, B. rufus, and B. pulchelus corresponds to the subgenus Bodianus, characterized by the presence in adult individuals of filamentous posterior extentions of the dorsal and anal fins (Gomon, 2006). The clade of Bodianus scrofa and Semicossyphus is chatacterized by a more temperate distribution and association with rocky bottoms, with B. scrofa inhabiting the Eastern Atlantic (Azores, Canary Island and Cape Verde) and the three species of Semicossyphus found in both the Eastern and Northwestern Pacific.

Our phylogenies, as well as all previous labrid molecular phylogenies

(Westneat and Alfaro, 2005; Alfaro et al. 2009; Cowman et al 2009; Kazancloglu et al.

2009) suggest that the taxonomic status of Bodianus requires major revisions, and that the tree species of Clepticus creole wrasses and the three species of Semicossyphus sheepheads should be reclassified as Bodianus.

The time calibrated phylogeny (Fig. 2) shows that all the major lineages of hogfishes originated in the Miocene, between $\sim 17 \mathrm{Ma}$ and 9 Ma. This time frame matches that of diversification for many other groups of reef-associated fishes that have their greatest diversity in the Indo-West pacific, including other wrasse lineages such as parrotfishes (Alfaro et al. 2009; Cowman et al 2009; Kazancloglu et al. 2009); 
surgeonfishes (Sorenson et al., 2013); pufferfishes, boxfishes, triggerfishes and filefishes (Santini et al., 2013a, 2013b, 2013c), several lineages of damselfishes (Cowman and Bellwood, 2011; Frederich et al., 2013) and butterflyfishes (Cowman and Bellwood, 2011).

Our timetree, together with the BioGeoBear analysis, suggests that hogfishes originated in the Indo-west Pacific and South-west Pacific, and that this group experienced several episodes of transition between biogeographic regions and Ocean basins. At least two episodes of invasion of both the Eastern and Western Atlantic occurred, as well as at least found events of invasions of the Western Indian Ocean and three episodes of invasions of the Eastern Pacific. All splits between Atlantic and Pacific sister lineages appear to consistently predate the "traditional" age of the closing of the Isthmus (3.1 Ma, Briggs and Bowen, 2012); however, this might be due to the fact that our sampling includes slightly less than the diversity of hogfishes and we are missing more recent lineages that might alter the age of the split between geminate species pairs.

A denser taxonomic sampling will be needed to determine with greater accuracy the routes of dispersal for some of these lineages and the timing of these events. For example, the current reconstruction suggests that the clade including Bodianus speciosus, B. eclancheri, B. perditio, B. bilunulatus and B. macrourus could have originated in the Eastern Atlantic, crossed the Atlantic to invade the Eastern Pacific and from there managed to recolonize the Indo-west Pacific and the Western Indian Ocean, but adding as yet unsampled species that belong to this group could suggest that the group was originally always distributed in the Indo-west Pacific and from that are a number of independend lineages manages to invade the Eastern Atlantic and the Eastern 
Pacific. In spite of this it is clear that hogfishes and their allies experienced a highly dynamic biogeographic history with repeated transitions between geographic regions.

\section{Acknowledgements}

We thank Peter Wainwright (UC Davis) and Mark McGrouther (Australian Museum) for loan of tissues used for this study. Funding for this project was provided by NSF grant DEB 0842397 "Systematics and Influence of Coral Reefs on Diversification in

Tetraodontiform Fishes." to MEA as well as by XSEDE grants TG-DEB140025 to FS.

\section{References}

Akaike, H., 1973. Information theory as an extension of the maximum likelihood principle, in: Petrov, B.N., Caski, F. (Eds.), Second International Symposium on Information Theory. Akademiai Kiado, Budapest, pp. 267281.

Alfaro, M.E., Santini, F., Brock, C.D., 2007. Do reefs drive diversification in marine teleosts? Evidence from the pufferfishes and their allies (order Tetraodontiformes). Evolution 61, 2104-2126.

Alfaro, M.E., Brock, C.D., Banbury, B.L., Wainwright, P.C., 2009. Does evolutionary innovation in pharyngeal jaws lead to rapid lineage diversification in labrid fishes? BMC Evol. Biol. 9, 255. 
Bacon, C. D., Silvestro, D, Jaramillo, C., Smith, B.T., Chakrabarty, P., Antonelli, P., 2015. Biological evidence supports an early and complex emergence of the Isthmus of Panama. Proc. Natl. Acad. Sci. USA 112, 6110-6115.

Briggs, J.C., Bowen, B. 2012. A realignment of marine biogeographic provinces with particular reference to fish distributions. J. Biogeography 39: 12-30

Carnevale, G., 2015. Middle Miocene wrasses (Teleostei, Labridae) from St. Margarethen (Burgenland, Austria). Paleontographica A, 304, 121-156.

Chen, W.-J., Bonillo, C., Lecointre, G., 2003. Repeatability of clades as a criterion of reliability: a case study for molecular phylogeny of Acanthomorpha (Teleostei) with larger number of taxa. Mol. Phylogenet. Evol. 26, 262288.

Chen, W.-J., Lavoué, S., Mayden, R.L., 2013. Evolutionary origin and early biogeography of otophysan fishes (Ostariophysi: Teleostei). Evolution 67, 2218-2239.

Cowman, P.F., Bellwood, D.R., 2011. Coral reefs as drivers of cladogenesis: expanding coral reefs, cryptic extinction events, and the development of biodiversity hotspots. J. Evolution Biol. 24, 2543-2562.

Drummond, A.J., Ashton, B., Buxton, S., Cheung, M., Cooper, A., Duran, C., et al. 2011. Geneious v5.4. URL http://www.geneious.com

Drummond, A.J., Rambaut, A., 2007. BEAST: Bayesian evolutionary analysis by sampling trees. BMC Evol. Biol. 7, 214. 
Edgar, R.C., 2004. MUSCLE: multiple sequence alignment with high accuracy and high throughput. Nucleic Acids Res. 32, 1792-1797.

Frédérich, B., Sorenson, L., Santini, F., Slater, G.J., Alfaro, M.E., 2013. Iterative ecological radiation and convergence during the evolutionary history of damselfishes (Pomacentridae). Am. Nat. 181, 94-113.

Froese, R., Pauly, D. 2014. FishBase. URL http://www.fishbase.org

Gomon, M.F. 2006. A revision of the labrid fish genus Bodianus with descriptions of eight new species. Rec. Aus. Mus. 30, 1-133.

Maddison, W.P., Maddison, D.R., 2011. Mesquite: A modular system for evolutionary analysis, version 2.75. URL http://www.mesquiteproject.org

Miller, M.A., Pfeiffer, W., Schwartz, T. 2010. Creating the CIPRES Science Gateway for inference of large phylogenetic trees. In Proceedings of the Gateway Computing Environments Workshop, New Orleans, LA pp 1

- 8.

Parenti, P., Randall, J.E. 2010. Checklist of the species of the families Labridae and Scaridae: an update. Smith. Bull. 13, 29-44.

Posada, D., 2008. JModelTest: phylogenetic model averaging. Mol. Biol. Evol. 25, $1253-1256$.

Rambaut, A., Drummond, A.J., 2009. Tracer v1.5. URL:

http://beast.bio.ed.ac.uk/Tracer 
Ronquist, F., Teslenko, M., van der Mark, P., Ayres, D.L., Darling, A., Höhna, S.,

Larget, B., Liu, L., Suchard, M.A., Huelsenbeck, J.P., 2012. MrBayes 3.2:

Efficient Bayesian Phylogenetic Inference and Model Choice across a Large Model Space. Syst. Biol. 61, 539-542.

Santini, F., Nguyen, M., Sorenson, M., Waltzek, T.B., Alfaro, J.W.L., Eastman, J.M., Alfaro, M.E. 2013a. Do habitat shifts drive diversification in teleost fishes? An example from the pufferfishes (Tetraodontidae). J. Evol. Biol. $26,1003-1018$.

Santini, F., Sorenson, L., Alfaro, M.E., 2013b. A new multi-locus timescale reveals the evolutionary basis of diversity patterns in triggerfishes and filefishes (Balistidae, Monacanthidae; Tetraodontiformes) Mol. Phylogenet. Evol. $69,165-176$.

Santini, F., Sorenson, L., Marcroft, T., Dornburg, A., Alfaro, M.E., 2013c. A multilocus molecular phylogeny of boxfishes (Aracanidae, Ostraciidae; Tetraodontiformes). Mol. Phylogenet. Evol. 66, 153-160.

Schultz, O., Bellwood, D.R., 2004. Trigonodon oweni and Asima jugleri are different parts of the same species Trigonodon juleri, a Chiseltooth Wrasse from the lower and middle Miocene in the Central Europe (Osteichthyes, Labridae, Pseudodacinae). Ann. Naturhist. Mus. Wien 105, 287-305.

Sevilla, R.G., Diez, A., Noren, M., Mouchel, O., Jerome, M., Verrez-Bagnis, V., et al., 2007. Primers and polymerase chain reaction conditions for DNA 
barcoding teleost fish based on the mitochondrial cytochrome $\mathrm{b}$ and nuclear rhodopsin genes. Mol. Ecol. Resources 7, 730-734.

Sorenson, L., Santini, F., Carnevale, G., Alfaro, M.E. 2013. A multi-locus timetree of surgeonfishes (Acanthuridae, Percomorpha), with revised family taxonomy. Mol. Phylogenet. Evol. 68, 150-160.

Stamatakis, A., 2006. RAxML-VI-HPC: maximum likelihood-based phylogenetic analyses with thousands of taxa and mixed models. Bioinformatics 22, $2688-2690$.

Ward, R.D., Zemlak, T.S., Innes, B.H., Last, P.R., Hebert, P.D., 2005. DNA barcoding Australia's fish species. Philos. Trans. Roy. Soc. B 360, 18471857.

Westneat, M.W., Alfaro, M.E., 2005. Phylogenetic relationships and evolutionary history of the reef fish family Labridae. Mol. Phylogenet. Evol. 36, 370390.

Williams, J. T., Carpenter, K. E., Van Tassell, J. L., Hoetjes, P., Toller, W., Etnoyer, P., Smith, M., 2010. Biodiversity Assessment of the Fishes of Saba Bank Atoll, Netherlands Antilles. PLoS ONE 5: e10676.

Yang, Z., 2006. Computational molecular evolution. Oxford University Press, Oxford. 
Figure and table legends

Figure 1. Bayesian phylogenetic hypothesis of Bodianus relationships based on analysis of the concatenated dataset using Mrbayes 3.2. Nodes that have PP greater than 0.95 and BSP greater than $90 \%$ are indicated by a star symbol $(*)$.

Figure 2. Bodianus timetree based on a Bayesian relaxed clock approach implemented in BEAST 1.8 Horizontal bars on each node indicate 95\% HPD confidence intervals.

Timescale at bottom of figure is in million years before present. All fish images modified under Creative Commons license from original photographs by J.E. Randall (retrieved from http://www.fishbase.org) with the exception of: Bodianus unimaculatus, licensed under Public Domain via Wikimedia Commons; Bodianus pulchellus originally posted to Flickr by Cliff, Licensed under CC BY 2.0 via Wikimedia Commons; Clepticus parrae, pone.0010676.g111 by Williams et al. (2010), licensed under CC BY 2.5 via Wikimedia Commons; Semicossyphus pulcher, by Gerick Bergsma , Attribution-Non Commercial 3.0 Unported (CC BY-NC 3.0) via Wikimedia Commons.

Figure 3. Preferred model of biogeographic reconstruction $(\mathrm{DEC}+\mathrm{J})$ according to biogeographic analysis of Bodianus species distribution. Abbreviations of geographic areas as follows: A, Western Atlantic; B, Eastern Pacific; C, Indowestern Pacific; D, Western Indian Ocean; E, South-western Pacific; F, Northwestern Pacific; G, Eastern Atlantic. 
Table 1. List of taxa included in this study with geographic distribution. Abbreviations of geographic areas as follows: W. Atl, Western Atlantic; E. Pac, Eastern Pacific; IW. Pac, Indo-western Pacific; W. Ind, Western Indian Ocean; SW. Pac, South-western Pacific; NW. Pac, North-western Pacific; E. Atl, Eastern Atlantic. 


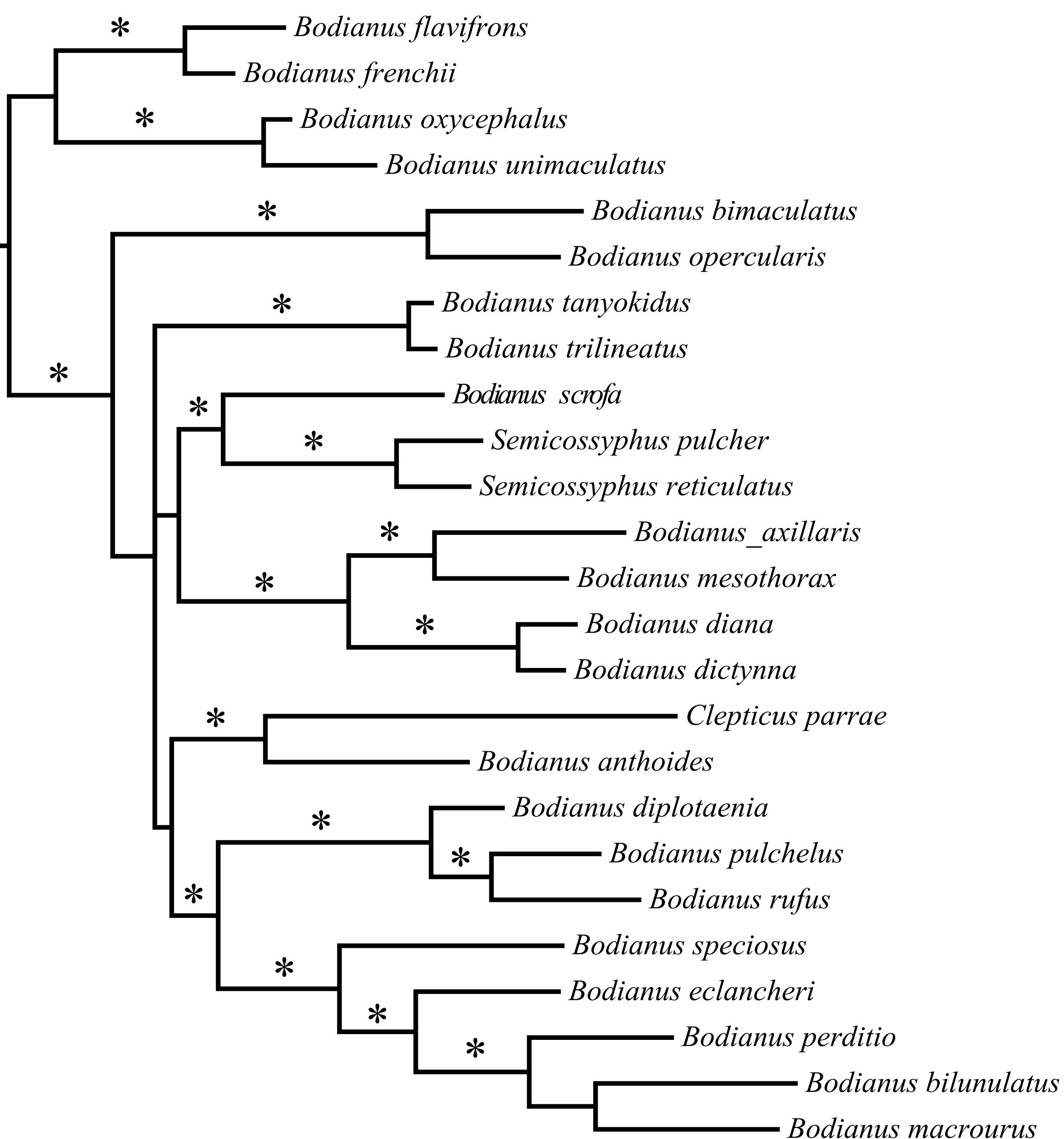




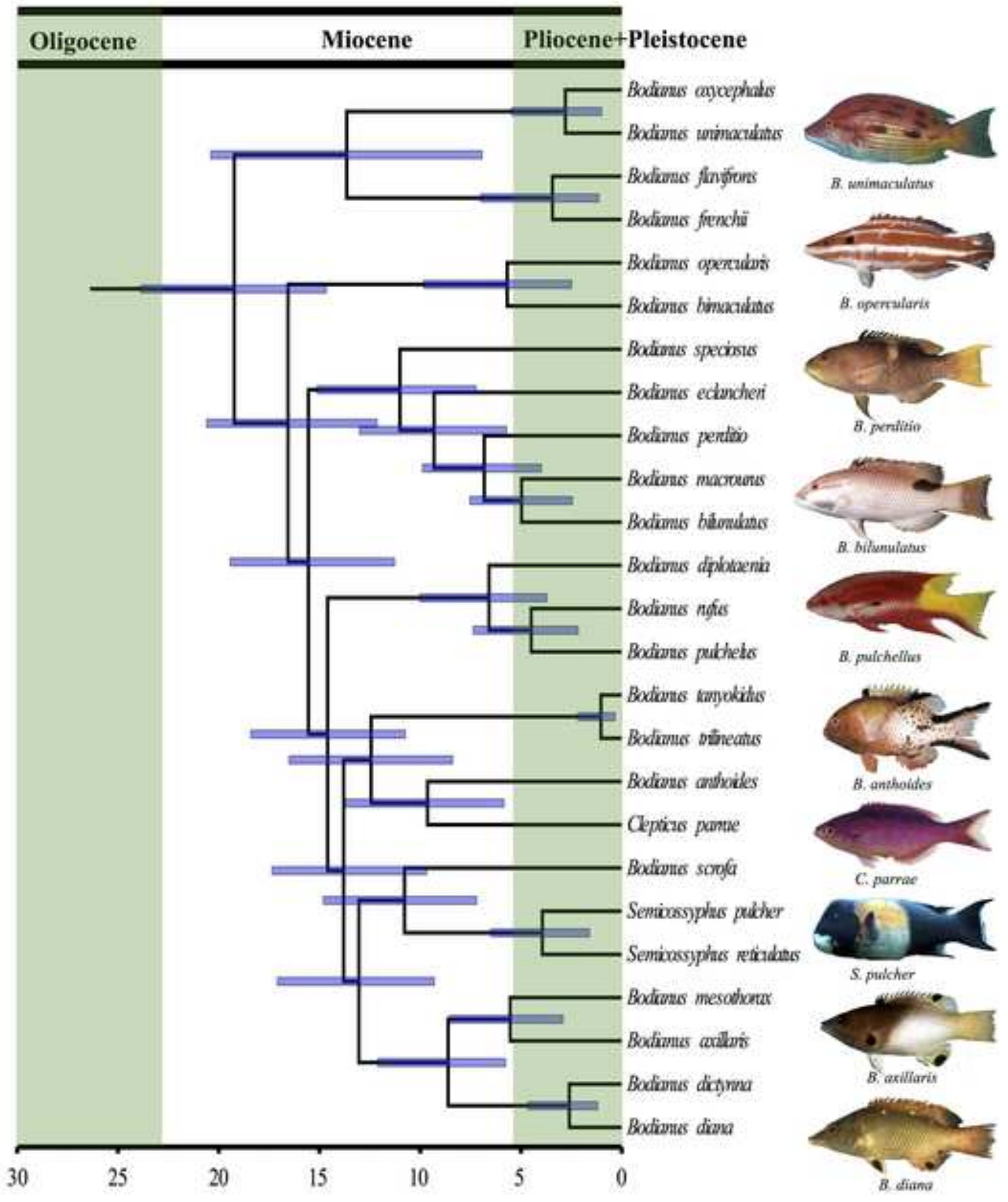




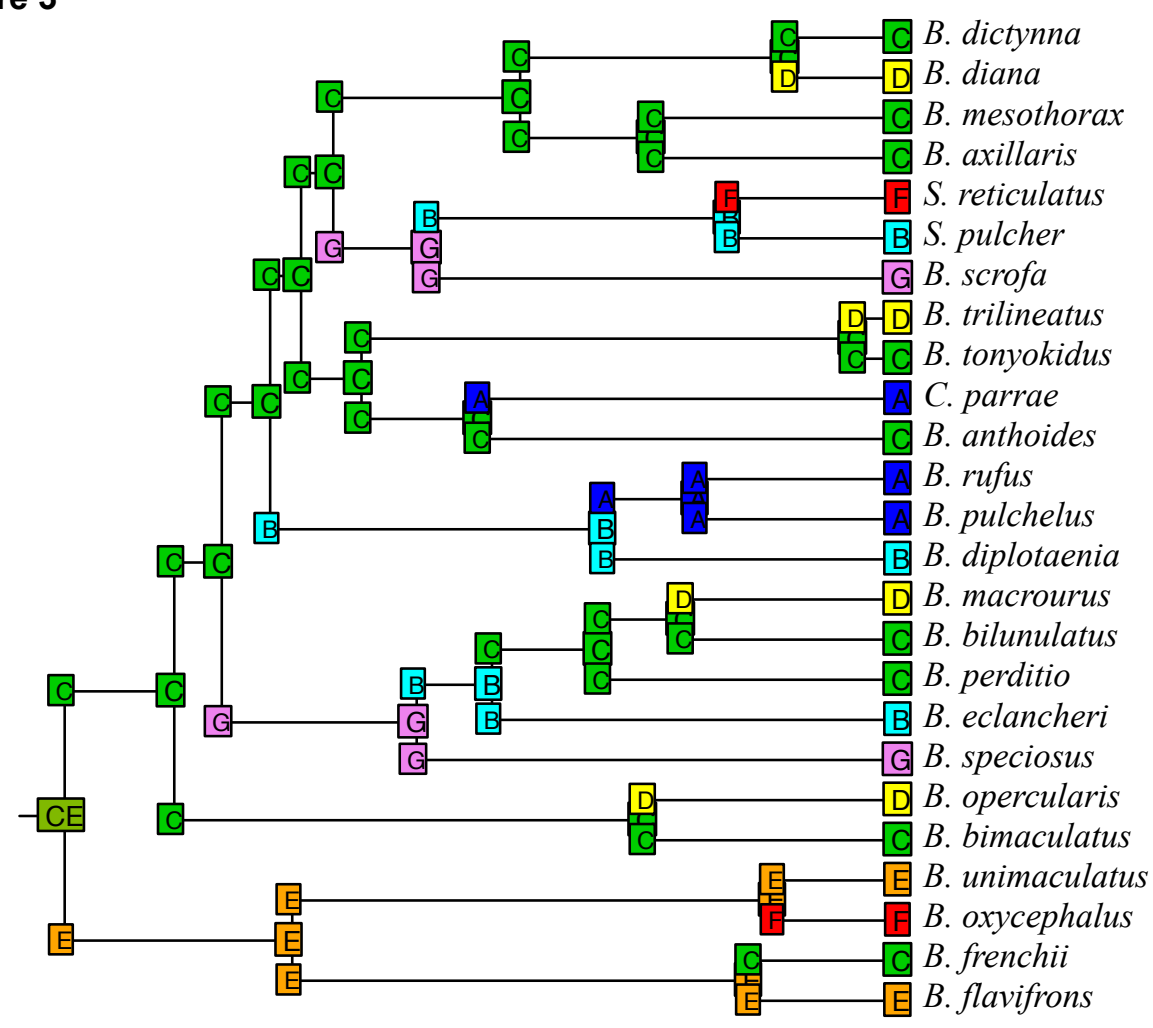

20

15

10

5

0

Millions of years ago 


\begin{tabular}{|c|c|c|c|c|c|c|c|}
\hline & W. Atl & E. Pac & IW. Pac & W. Ind & SW. & NW. & E. Atl \\
\hline (areas in Fig 3) & $\mathbf{A}$ & B & $\mathbf{C}$ & D & $\mathbf{E}$ & $\mathbf{F}$ & $\mathbf{G}$ \\
\hline B. anthoides & 0 & 0 & 1 & 0 & 0 & 0 & 0 \\
\hline B. axillaris & 0 & 0 & 1 & 0 & 0 & 0 & 0 \\
\hline B. bilunulatus & 0 & 0 & 1 & 0 & 0 & 0 & 0 \\
\hline B. bimaculatus & 0 & 0 & 1 & 0 & 0 & 0 & 0 \\
\hline B. diana & 0 & 0 & 0 & 1 & 0 & 0 & 0 \\
\hline B. dictynna & 0 & 0 & 1 & 0 & 0 & 0 & 0 \\
\hline B. diplotaenia & 0 & 1 & 0 & 0 & 0 & 0 & 0 \\
\hline B. eclancheri & 0 & 1 & 0 & 0 & 0 & 0 & 0 \\
\hline B. flavifrons & 0 & 0 & 0 & 0 & 1 & 0 & 0 \\
\hline B. frenchii & 0 & 0 & 1 & 0 & 0 & 0 & 0 \\
\hline B. macrourus & 0 & 0 & 0 & 1 & 0 & 0 & 0 \\
\hline B. mesothorax & 0 & 0 & 1 & 0 & 0 & 0 & 0 \\
\hline B. opercularis & 0 & 0 & 0 & 1 & 0 & 0 & 0 \\
\hline B. oxycephalus & 0 & 0 & 0 & 0 & 0 & 1 & 0 \\
\hline B. perditio & 0 & 0 & 1 & 0 & 0 & 0 & 0 \\
\hline B. pulchelus & 1 & 0 & 0 & 0 & 0 & 0 & 0 \\
\hline B. rufus & 1 & 0 & 0 & 0 & 0 & 0 & 0 \\
\hline B. scrofa & 0 & 0 & 0 & 0 & 0 & 0 & 1 \\
\hline B. speciosus & 0 & 0 & 0 & 0 & 0 & 0 & 1 \\
\hline B. tanyokidus & 0 & 0 & 1 & 0 & 0 & 0 & 0 \\
\hline B. trilineatus & 0 & 0 & 0 & 1 & 0 & 0 & 0 \\
\hline B. unimaculatus & 0 & 0 & 0 & 0 & 1 & 0 & 0 \\
\hline C. parrae & 1 & 0 & 0 & 0 & 0 & 0 & 0 \\
\hline S. pulcher & 0 & 1 & 0 & 0 & 0 & 0 & 0 \\
\hline S. reticulatus & 0 & 0 & 0 & 0 & 0 & 1 & 0 \\
\hline
\end{tabular}




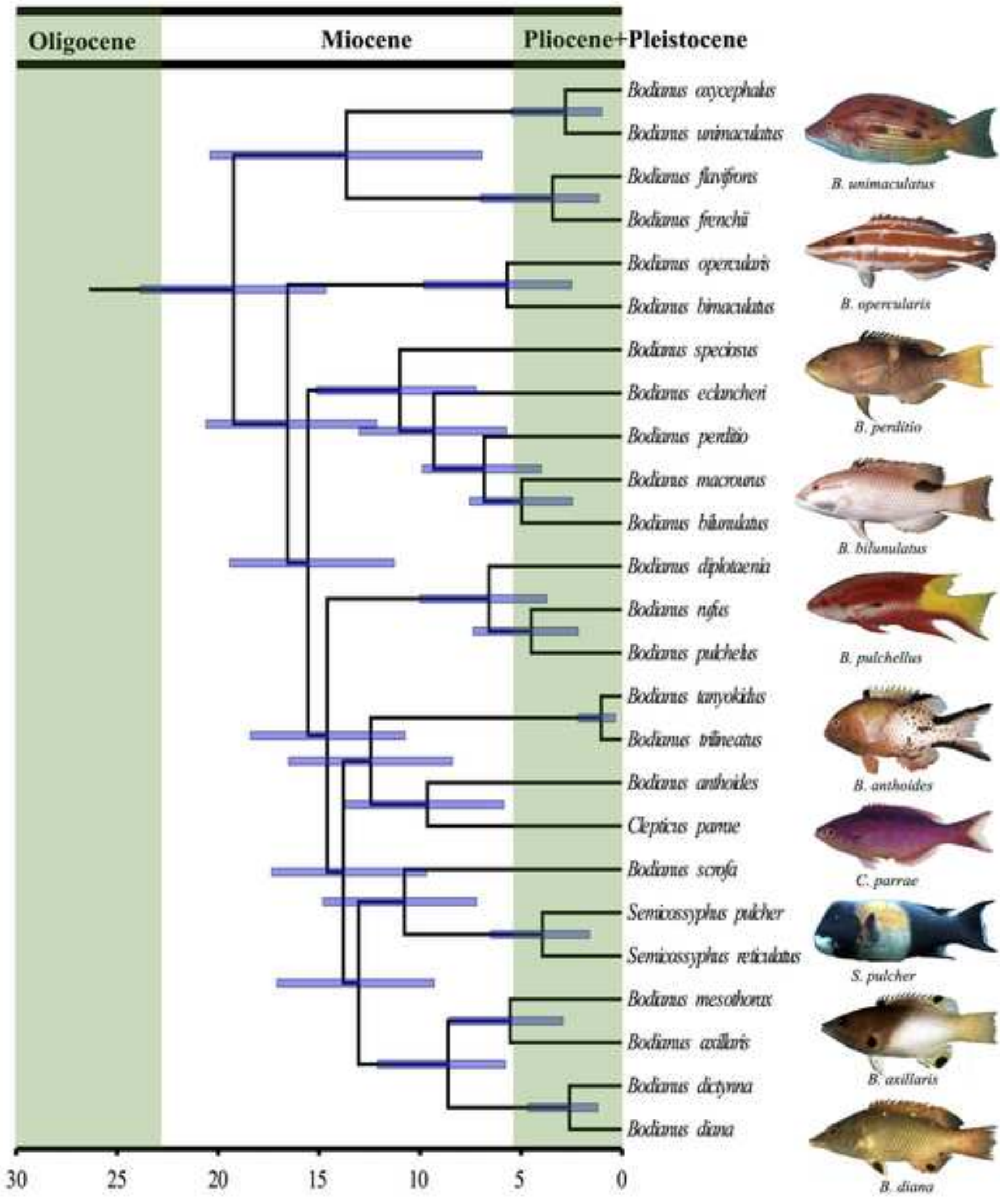

